\title{
Violent Crime on American Television: A Critical Interpretation of Empirical Studies
}

\author{
Amir Hetsroni \\ School of Communication, Ariel University Center of Samaria, Ariel, Israel \\ Email: amirhetsroni@gmail.com
}

Received January 19 th $^{\text {th }}$ 2012; revised February 25 ${ }^{\text {th }}$ 2012; accepted March 21 ${ }^{\text {st }}, 2012$

\begin{abstract}
This article reviews six decades of studies regarding the presentation of violent crime on American television, and its impact. We critically discuss the major findings and analyze the political-public discourse regarding the macro-social effects of fictional and non-fictional televised violent crime. The claim made here is that this discourse created "too much fuss over not too much blame" in order to mark television as the agent in responsibility for social atrocities.
\end{abstract}

Keywords: Television; Violent Crime; Violence; Content; Effect; News; Drama; USA; Public Policy

\section{Introduction}

Is television violence really the reason for no less than 10,000 homicide cases in the USA alone-as suggested by a renowned criminologist (Centerwall, 1989)? There is, of course, no empirical way of testing the accuracy of this claim, but one cannot deny that that three out of four Americans think that there is a relationship between violence on television and the national crime rate (Saad, 2007), and that a majority of the American public feel that television crime shows, violent films and television news items about crime contribute a lot to the seemingly high US murder rate (Potter, 2003).

It is true that since the inception of commercial broadcasting in the early 1950s, the home screen has been swept with a long line of screened and non-screened programs portraying violent crime. From the Naked City and the Untouchables in the 1950s and 1960s to the Sopranos and Rescue 911 in the 1990s and 2000s, viewers have been exposed to a considerable amount of interpersonal and collective aggression, gunshots, gory images and even death (Roman, 2005). However, it is also true that the direct behavioral effect of prolonged routine exposure to violent programs is very small by social science standards, mounting to less then three percent of the variance (Paik \& Comstock, 1994), and decreases further below the one percent of the variance threshold, when actual violence is used as an indicator (Grimes, Anderson \& Bergen, 2008). Still, many voices from within the academic community (see Bushman \& Anderson, 2001), along with politicians, have been treating the appearance of violent crime of television broadcasts as a serious problem. The late Senator John Pastore declared, for example, that television violence is "a public health risk". So profound is the belief in the potency of violent programming to nurture violent crime, so that when asked to select measures that would significantly reduce the level of this crime, Americans choose restrictions on the presentation of violence on television more frequently than they suggest firmer gun control regulations (Lichter, Lichter, \& Rothman, 1994: p. 30).

This article reviews many of the studies that questioned the presentation of violent crime on the American home screen through the years, critically discusses their findings and ana- lyzes the political-public discourse regarding macro-social effects. Our main claim is that this discourse created "too much fuss over not too much blame" in an attempt order to mark television as the responsible agent for social atrocities.

\section{Theoretical Frameworks to Studying the Contents and Effects of TV Crime}

The history of media research begins in the period leading up to World War II. Television was not yet present, but radio and cinema had a substantial grip in our culture, and raised the attention of sociologists, psychologists and criminologists, who questioned the amount of crime carried mostly by films and the impact of exposure to this mediated presentation of crime. Much of the scholarship exhibited concern about the consequences of this exposure (Lowery \& DeFleur, 1995). A popular metaphor used in that period for the effect of media was hypodermic needle, connoting the idea that the media inject messages to mass audiences that lack any power to resist (Lasswell, 1935). The content of messages gave another reason for concern, as even in those days the silver screen had already been saturated with crime and violence. Scholars were worried that if watching films in the theater house once or twice a week can be considerably influential-television might pose an immense risk (Lowery \& DeFleur, 1995). However, a long series of studies, commencing in the 1950s, have acknowledged the fact that television's direct contribution to actual crime is very modest. These findings led to the law of minimal consequences as a general description of the behavioral immediate effects of media exposure (Klapper, 1960).

This law, however, did not deter media researchers from continuing to look for the blame in the tube. One line of research isolated viewers in labs in search for behavioral effects. Despite some evidence that shows that violent behavior can be learned through observational imitation, especially when the learners are young children (Bandura, 1994), the overall pattern of results from natural settings is mostly inconsistent. Studies of inmates have failed to detect a heavy diet of violent media among felons convicted of violent crime (Goldstein, 1973). Copycat offenses, which are one to one imitations of crimes 
that had been reported in the media a short while before the commission of the acts, that some see as a direct media effect, are actually very rarely linked to media exposure (Pease \& Love, 1984).

A second line of research attempted used the reality construction metaphor, which contends that our understanding of the world is gained by studying its shared meanings, which are not directly and entirely dependent on empirical validity, but are strongly influenced by the interaction with mediating sources of knowledge, such as television (Weimann, 2000) in an attempt to point at a link between the frequency of crime on the screen and the actual crime level. Reality construction studies consist of two phases: the first documents media reality and finds out where it diverts from the actual course of things in the world; the second asks media consumers to assess the lifeblood of occurrences in the world and attempts to detect similarities between media reality and a distorted estimation, particularly among heavy TV viewers (Weimann, 2000).

\section{The Presentation of Violent Crime on TV}

With the exception of specialty news channels, most of the TV content that is carried by commercial broadcasters can be defined as "fictional-entertainment" (or "infotainment" in the case of some of the reality programs). Very soon after commercial broadcasting had taken off, researchers were already noticing the ubiquitous presence of crime in the medium's offerings. Even in the 1950s, when television was still epitomized by relatively innocent plotlines (Lichter et al., 1994), nearly one fifth of the protagonists in prime-time programs were criminals or law enforcers (Head, 1954; Smythe, 1954). These numbers, which are several times higher than comparable population figures, have persisted for decades (Dominick, 1973; Maguire, 1988; Diefenbach \& West, 2001).

However, not all sorts of violent crime are equally over-represented on the screen. Using figures issued by the US Department of Justice as benchmarks, Diefenbach and West (2001) found that murder is one-thousand times more present on the small screen, but rape is three times less present, and robbery and aggravated assault are more or less similarly represented. Overall, TV drama is approximately fifty-percent richer in violent crime and ten-times poorer in non-violent property crimecompared to what actually goes on in America.

Television drama has been introducing two types of criminals: The professional deviant who lives a life of crime and the established denizen who turns to crime to maintain or improve his standard of living (Lichter \& Lichter, 1983). The first type enjoys non-recurring roles in police drama, courtroom drama and medical drama. His personality is rarely analyzed in depth, and his partaking in the program is mostly limited to his involvement in the crime scene. The second type of criminal has leading roles and multifaceted personality. His decision to choose crime as a profession constitutes a significant part of the plot and receives an explanation, if not a justification. A good example is the character of Toni Soprano in The Sopranos-a godfather who runs a criminal organization as a family business. The TV criminal of this type tends to belong to the upper or middle class. He is often presented as a businessman whose pursuit of profit leads to performing illegal actions.

In sharp contrast with reality-where convicted criminals over-represent people under the age of 25 , and in particular young black - on television the vast majority of criminals are white males aged 30 to 40 years old (Lichter \& Lichter, 1983; Brown, 2001). This over-representation of Caucasians in criminal roles sends, perhaps unintentionally, a somewhat utopian message about the behavioral nature of minorities.

Women are under-represented among TV felons, just as they are under-represented in the criminal population in the real world. While the ratio of males to females in leading and supporting roles in drama and comedy has been-according to different studies-approximately one to two (Greenberg \& Collette, 1997; Greenberg, Simmons, Hogan, \& Atkin 1980), among criminal characters this ratio has fluctuated between one to ten (in 1968) and one to three. Over the decades, there was a slight increase in the share of female criminals, but this change is minor in size and does not conceal the lingering unequivocal message of popular TV programs: criminal behavior is not a viable option for women as it is for men (Hetsroni, 2007). This is part of a generally conservative worldview of gender roles, typical of popular programming, which finds expression in the portrayal of family life, occupations and child rearing (Greenberg \& Collette, 1997).

In terms of occupation, television criminals are seldom identified in any way other than as criminals or law enforcers who crossed the line (Dominick, 1973). More than one third of the criminal characters are gangsters, thieves or own an organized crime network. Second in share, come law enforcers (policemen, lawyers etc.) who switched sides. Businessmen and free occupations e.g. doctors, architects make up the third major source of criminal characters (Lichter \& Lichter, 1983). Blue collar occupants are rarely depicted as criminals, even though in the real world this group contributes abundantly to the population of thieves and unarmed robbers (Maguire, 1988). However, since petit crime is rarely seen on the screen, one can say that actually the exclusion of blue collar occupants from the pool of criminal protagonists is realistic in its way. Economically speaking, TV criminals tend to be rich people: From boss Hogg in Dukes of Hazzard in the 1970s to Toni Soprano in The Sopranos in the 2000s not much as changed in the socio-economic profile of criminals in TV drama television content (Roman, 2005), which continues to contradict real world statistics according to which most of the criminals are of the lowest economic tires (Lichter \& Lichter, 1983; Maguire, 1988). The twisted racial-economic TV portrayal of criminals stretches on to convicts: Prison cells in TV drama are full of older rich white males, while in the real world many inmates are poor young blacks. One aspect where the TV picture does resemble the real world is the tendency towards recidivism in criminality: Most of the people who are arrested on the screen, just like most of the people who are arrested by the police, have been arrested before (Lichter \& Lichter, 1983).

Crime on television is carefully contemplated in $60 \%$ of the cases. Greed, revenge and mental illness serve as primary motives (Lichter et al., 1994). It is difficult to compare this finding with real world statistics, since there is no official notation of criminal motivations for all crimes. However, the FBI does publish statistics regarding motives and circumstances surrounding homicides. On television, murders are meticulously planned, whereas in real life murder is most often a crime of passion, a result of momentary annoyance such as reaction to hostile argument (Surrete, 1998). As for the victims of TV criminals - they are portrayed as passive and helpless with an over-representation of white people in general and young white females in particular. This demography resembles the viewers' 
fear of being subject to crime more than it represents actual victimization risk (Scheingold, 1984).

Which sorts of crime are most often depicted in TV drama? Table 1 summarizes the most frequent crimes according to four studies conducted in different decades.

While the numbers have fluctuated over the years, murder is a highly frequent crime across the board and property crime is a rare occurrence. This contradicts official statistics, which point at property crime, particularly theft and larceny, as the most frequently reported crime, subject to over $80 \%$ of the cases known to the police (Maguire, 1988). The implied message to viewers is that violent crime (murder, armed robbery, aggravated assault) and not property crime is what people face more often in daily life.

News programs present a picture of crime that bears a lot of similarities to what is shown in fictional programming, but the news has few unique nuances. Just as in drama, the news, too, present homicide as the most frequent crime, but in contrast with drama the news present a somewhat larger share of white collar crime (often in relation to political scandals) and sensational sex related crime (Sheley \& Ashkins, 1981). A distinctive example of sensational coverage of crime, which packs together politics and sex, is the New York State governor Elliot Spitzer use of escort service and his alleged use of campaign money to pay for the service. In 2008, this affair took an unprecedented share of local and national news airtime, although the crime itself was classified as no more than misdemeanor in the eyes of the law. The extensive coverage of sensational crime has to do with its rarity, as the media prefer to report on the unusual and leave the expected out of the screen. Murder makes up only $0.2 \%$ of the crime known to the police, but it is the subject of more than a quarter of crime news stories, because it is dramatic and infrequent (Graber, 1980; Surette, 1998).

Of course, the police and the justice system put efforts to publish "success stories" in news magazines. This increases the chances of resolved crime stories to get published. These stories are prepackaged, so that the broadcaster's task in assembling the report is minimal. In broadcasters' jargon such stories receive the unflattering title "garbage crime". They are aired only when the station has nothing better to air (Surette, 1998). At a higher level, we find news stories that report on crime, where noted public figures and celebrities are involved, either as offenders or as victims. To cover these stories, termed "OJ felonies" (in the name of O. J. Simpson), journalists search for additional information, beyond what is supplied by the police, the defense attorney etc. Thus, the news reporter becomes a significant gatekeeper of information (Berkowitz, 1990). Overall,

Table 1.

The most frequent crimes in TV drama.

\begin{tabular}{ccccc}
\hline Crime & $\begin{array}{c}\text { Dominick } \\
(1973)\end{array}$ & $\begin{array}{c}\text { Lichter \& } \\
\text { Lichter (1983) }\end{array}$ & $\begin{array}{c}\text { Maguire } \\
(1988)\end{array}$ & $\begin{array}{c}\text { Brown } \\
(2001)\end{array}$ \\
\hline Homicide & $22 \%$ & $24 \%$ & $48 \%$ & $79 \%$ \\
Armed robbery & $6 \%$ & $18 \%$ & $2 \%$ & $3 \%$ \\
Aggravated assault & $29 \%$ & $8 \%$ & $12 \%$ & $6 \%$ \\
Rape & $0 \%$ & $2 \%$ & $1 \%$ & $1 \%$ \\
$\begin{array}{c}\text { Fraud/White collar crime } \\
\text { Theft and non-violent } \\
\text { property crime }\end{array}$ & $6 \%$ & $3 \%$ & $1 \%$ & $0 \%$ \\
\hline
\end{tabular}

most of the crime remains unreported: in a study of local news, only 15 of 1741 felonies investigated by the police over a three month period were mentioned in the news (Fedler \& Jordan, 1982). Nonetheless, crime and justice items still make up a prominent share of the news - ten to fifteen percent in local news programs and around $20 \%$ in national news magazines (Graber, 1980).

The typical treatment of crime does not refer to it as "a social problem” but covers criminal incidents as discrete events. Thus, the implied message is that responsibility for committing the crime resides almost exclusively with the individual criminal (Surette, 1998). Who are the criminals according to crime news? Like in entertainment programming, crime news bring to fore greedy businessman as perpetrators of white collar crime, and present professional predators and organized crime moguls as responsible for violent transgression of the law, but in contrast with TV drama-the news frequently present bureaucrats and civil servants as criminals who breech public trust (Terry, 1984). The most ignored group of criminals in TV news are poor young men, who do not belong to any criminal organization but do commit property crime which is sometimes violent but more often not (Surette, 1998). The victims, according to television crime news, tend to be females, who are considerably young or exceptionally old, and/or of high social status. This mode of portrayal, which contradicts real life circumstances, where most of the victims of violent crime are males, assists in construing a narrative of crime as an intended action in of strong men to exert power on physically weak women (Meyers, 1994).

The criminal justice system is described mostly as a punitive organization. Since crime is presented as an individual choice, the function of the system is to punish the sinners and correct the deviants. The system is evaluated according to its success in doing so, namely changing the criminal habits of individuals (Graber, 1980).

Finally, a new sub-genre, infotainment, which emerged in the 1990s, blurs the line between news magazines and entertainment programming. Shows such as Cops and Rescue 911 present actual crimes in a realistic light-sometimes in reenactments, sometimes as dramatized stories, and sometimes in documentary-style stories. These programs tend to concentrate on bizarre violent crime, and present stereotypical portraits of predatory evil criminals and helpless victims. The gruesome is shown as the mainstay of modern life (Jermyn, 2006). The content of these shows is often an over-exaggeration of crime drama, but the apparent realism makes it more credible.

\section{Does TV Crime Pay Off and Does It Curb Potential Harmful Effects Off-Screen}

Does crime pay? Statistically speaking, the answer in the real world is commonly yes, since around two thirds of the cases reported to the police remain unresolved. Television is a totally different sphere. On the screen, nearly $60 \%$ of the crimes are solved (Lichter \& Lichter, 1983). The juridical procedure in the real world is a multi-step saga, where many of the phases are less than dramatic, and where most of the cases end in a nonceremonial deal between the prosecution and the defense. Television concentrates on cases that do reach a verdict, and highlights the more dramatic phases of the juridical procedure. In past decades, episodes of police or courtroom drama nearly always ended in a conviction of the criminal. Recent programs such as Law and Order and Boston Legal do leave an open-end 


\section{A. HETSRONI}

from time to time, or let the criminal sneak out unpunished (Roman, 2005), but the conviction rate of TV criminals remains impressively high. This sends a clear message to the audience: Crime does not pay off, since law enforcers put things in order (Stark, 1987). Here is the place to emphasize: While crime shows and cop shows may be about law and order, in practice they are light on law and heavy on order (Lichter et al., 1994). This tone has led to a number of concerns about the message and its implications. On the one hand, concerns are about unrealistic expectations that viewers may develop about the ability of the police; on the other hand, the programming' dismissal of negative police behaviors such as overuse of guns and lack of consideration of detainees' rights may encourage disregard of human rights in the name of security (Surette, 1998). Generally, the media portray the justice system as a malfunctioning organization, saved occasionally by lonesome heroes (attorneys, private detectives, police officers) whose actions go against the mainstream. However, paradoxically, it is the presentation of the justice system as malfunctioning that encourages expectations for harsh punishment as the only effective way to avoid dealing with the same criminals once and again (Bortner, 1984).

\section{How Criminal Is Television?}

The claim about the negative effects of TV crime assume that the screen is loaded with shows abundant with violent crime and that these shows are successful i.e. attract large numbers of viewers. To examine the accuracy of these assumptions we follow the percent of the "most criminal genre"-crime drama and action-adventure programming in the prime-time lineup of the major networks over the years and the rating figures obtained by these shows. Figure 1 shows the percent of crime drama and action-adventure programming that were shown in ABC, CBS, NBC and FOX between 1970 and 2006. The classification of the programs is based on descriptions appearing the TV Guide directory (TV Guide, 2006).

On average, over the years, about $20 \%$ - $25 \%$ of all primetime shows have focused on crime and law enforcement. There were two golden eras - the mid 1970s, when police drama such as Starskey \& Hutch and Kojak and action-adventure series like Charlie's Angels and Dukes of Hazard were major staples of prime-time, and the mid 1980s, when the A-Team adventures and Magnum P.I. investigations dominated the airwaves, but the overall pattern points at a rather steady presence of crime programming with periodical ebb and flow.

Rating wise, over the years, crime dramas have not been among the industry's most notable blockbusters, nor were they

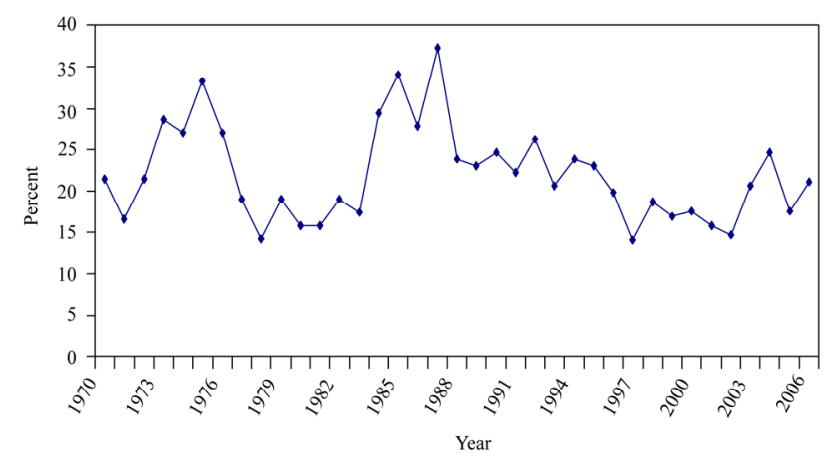

Figure 1.

Percent of Network prime-time programs featuring crime. considered to be the most enjoyed programs in the eyes of the general public (Diener \& DuFour, 1978). In the last two decades only one show that emphasizes crime Rescue 911 was in the top ten of the ratings chart. One reason for the relatively low ratings could be the scheduling of crime drama in the later part of the prime-time slot (10 pm-11 pm), when many viewers are already sleeping and others are excruciatingly tired. However, this scheduling is not arbitrary. It is an effective economic move in light of the shows' failure to attract a larger bulk of the public at large. Most of the viewers of violent programming are men above the age of 50 or in the age bracket of 18 -24, often high school or college dropouts (Comstock, Chaffee, Katzman, McCombs \& Roberts, 1978). Economically speaking, this cluster does not constitute the most sought for population. Programs that attract these viewers are nonetheless desired by some advertisers, but they constitute just a narrow niche (Comstock \& Scharrer, 1999). The distinctive demographic composition of crime drama viewership can explain the lingering presence of the genre on the small screen despite its moderate ratings. The niche status of the genre has even been strengthened recently with the proliferation of cable channels such as Spike, which target less-educated males and concentrate on crime programming.

\section{Effects of TV Crime on Individuals and Society}

The surreptitious and unexpected nature of crime in the real world makes isolating and assessing the direct impact of single factors, such as television, impractical in most of the cases. As a result of that, most of the conclusions regarding the influence of television on crime level are indirect, historical or derived from artificial laboratory experiments.

A popular approach among researchers is to treat crime as an expression of violence, and to suggest that an intensive televised depiction of violence brings about aggression among the viewers (through observational learning), which in turn results in increased amounts of crime. This proposition suffers from a number of deficiencies. First, even though crime is routinely presented on television broadcasts, which target large numbers of viewers, and although these viewers normally have no alternative source that exposes them to such crime-in practice over $90 \%$ of the crime on the street is not violent and consists of offenses rarely shown on television. Evidence from historical aggregate crime rate studies indicates that the introduction of commercial broadcasting in the USA was associated with an immediate increase in the rate of property crime but not an increase of violent crime (Hennigan, Heath, Wharton, Del-Rosario, Cook \& Calder, 1982). One study was able to point at an increase in the level of violent crime-but only 10 to 15 years after television was introduced (Centerwall, 1989). The author's suggestion that the criminals needed a number of years to absorb the message does not sound convincing, as he disregards a more plausible explanation that connects the rise in violent crime in America in the 1960s with the political turmoil of the era. Further shadow of doubt on the relationship between the level of violent crime in society and the depiction of violent crime on television is cast by the fact that the level of violent crime in America decreased steadily throughout the 1990s, even though violence remained present on the screen throughout the decade. The immediate correlation between crime rate and the appearance of crime in fictional American TV programming is negligent (Potter, 2003). Another study examined 
the patterns of 140,000 US homicides from 1973 to 1979 , which took place before and after TV news reports about prizefights, murder acquittals, life sentences and executions, and found out that the number of homicides showed a significant increase several days after the TV report (Philips \& Hensley, 1984). However, this research disregarded the fact that gang crime and homicides happen as ebb and flow due to factors such as gang rivalry and revenge that have nothing to do with the media. Furthermore, the effect detected in that study, although statistically significant, covered barely one percent of the variance.

Laboratory experiments found greater effects, but they often used amateur films as stimuli and operationalized criminal intention as the willingness to administer an imaginary shock to a research confederate-a twisted definition by all means. Furthermore, even lab studies revealed that televised depictions of violence do not affect all the viewers in the same way. A number of factors - from momentary frustration to hypermasculine personality—play into the media's effect (Comstock, 1983).

Only one mass-scale work took a longitudinal approach. Eron and Huesmann (1980) surveyed young people in two different time periods: when they were nine years old and when they were thirteen years old. The researchers detected a positive correlation between the kids' preference for violent programming, when they were nine years old, and their violent behavior four years later, but they also found out a positive correlation between the kids' violent behavior in primary school and their violent behavior as teens. As a result of that, it is difficult to determine if the violence at a later life stage was caused by earlier media exposure, or whether the subjects' aggressive nature motivated them to act violently as teens and to consume violent media as kids. Even more perplexing is the lack of correlation between the teens' tendency to act violently and their media diet as adolescents.

The despair from detecting behavioral effects of significant size that can be unequivocally ascribed to watching crime on television led the scientific community to look for a different kind of impact and adopt the reality construction metaphor. Researchers were able to establish a small but significant correlation between the amount of time devoted to television viewing and overestimating the number of criminals (Gerbner, Gross, Eleey, Jackson-Beeck, Jeffries-Fox, Signorielli, 1977; Hetsroni \& Tukachinsky, 2006) and perceiving violent crime as a serious problem (Doppelt \& Manikas, 1990). However, when it comes to more profound dispositions, the findings are more ambiguous. On the one hand, there is a correlation between the overall amount of time devoted to television viewing and seeing the world as a dangerous surroundings and the mean world index set of questions (Do you think most people would try to take advantage of you if they got a chance or would they try to be fair?"; "Would you say that most of the time people try to be helpful, or that they are mostly just looking out for themselves?”; Generally speaking, would you say that most people can be trusted or that you can't be too careful in dealing with people?) composed by Gerbner and his colleagues to measure what they term cultivation, namely the ability of television to enculturate suspicion and mistrust among the viewers (Gerbner, Gross, Morgan, Signorielli, \& Shanahan, 2002). On the other hand, the more recent work of Apple (2008) shows that the mean world index is associated with general viewing, but watching fictional programming (including crime drama) is actually statistically related to a just world syndrome i.e. be- lieving that justice and not injustice is the norm in our society. The researcher explains that the message connoted by drama, where justice almost always wins, is often different from the message carried by the news. This way or another, the bottom line, again, indicates small effects that are more dispositional than behavioral. Furthermore, even the disposition applies more to general fears of crime and less to worries about specific misconducts (Heath \& Gilbert, 1996).

\section{TV Crime and Public Policy}

Very early in the history of commercial broadcasting, American politicians have expressed concern over TV portrayal of crime and commented that something ought to be done about this. In 1952, the Commerce Committee of the House of Representatives held the first political hearing on the subjectseeking to determine whether television programs contained offensive material or emphasized crime and violence. Throughout the next decade, several congressional and senate hearings followed, culminating in the conclusion that further research is needed to determine whether television viewing is dangerous to society and individuals (Donnerstein \& Linz, 1995; Signorielli, 2005). However, for officers appointed by politicians to serve as regulators in the FCC, the answer appeared to be very simple:

Millions of television receivers are pouring an unending stream of crime, violence, outright murder, brutality, unnatural suspense and horror into the living rooms of America... The suggestions that there is no discernible relationship between these programs and the recent appalling increase in juvenile delinquency, in my opinion, flout common sense (Testimony of FCC officer before the US Senate Judiciary Committee on Juvenile Delinquency in the United States, 1955_cited in Surette, 1998: pp. 116-117).

In the 1960s and 1970s, the US Surgeon General appointed two committees to scientifically investigate the relationship between TV violence and violence in American society. Both of the committees reached the conclusion that there is probably a connection between the two, but that relationship is not very strong and is heavily mitigated (Signorielli, 2005). The broadcasters have kept on claiming that the research findings are not conclusive, and that the study conditions are too artificial to bear enough resemblance to the real world (Donnerstein \& Linz, 1995). No longstanding regulatory decision was made (Signorielli, 2005). In the 1980s, the political-public discourse regarding the operation of the TV industry revolved around market deregulation, and the issue of televised crime and violence was left mostly off the table. The 1990s saw renewal of the debate expressed in congressional and senate hearings and further research that eventually led the "advisories compromise", which became part of the 1996 Telecommunication Act: According to this compromise, the broadcasters agreed to add marking advisories to violent programs that viewers can use as a guideline to avoid exposure to violent shows (Potter, 2003). That agreement also marked the demise of the longstanding public discussion concerning the hypothesized connection between presenting crime on television and crime in American society (Grimes et al., 2008). This happened for two reasons. First, the increasing penetration of the internet brought with it the notion that dealing with the effects of exposure to moderately violent content on television at a time when much more aggressive contents are readily available on any computer is outdated (Signorielli, 2005). Second, the discussants were pro- 
bably exhausted of failing to locate the "smoking gun" in media violence and started to search for it under "media sex".

\section{Summing Words}

What lesson should we learn from the analysis? It is probably possible to establish some relationship between being exposed to violence on television to disposition towards violence, which then may translate to some increase in the level of violent crime. However, the attention given to this connection by the scientific community, politicians and the public at large is all but proportional to its size. This article does not aim to explain the motivations behind ascribing so much power to such small effect, but it is obvious that in contrast with other factors that encourage acts of violence such as family, friends, schools and the welfare system - the media system is probably the most eagerly willing to serve as a scapegoat. Finally, a few words of caution are due about the scope of the conclusions. The studies we have reviewed took place mostly in the United States. Even though American TV shows are broadcast worldwide, we cannot automatically generalize the findings to other cultures.

\section{REFERENCES}

Apple, M. (2008). Fictional narratives cultivate just world beliefs. Journal of Communication, 58, 62-83.

doi:10.1111/j.1460-2466.2007.00374.x

Bandura, A. (1994). Social cognitive theory of mass communication. In J. Bryant, \& D. Zillman (Eds.), Media effects: Advances in theory and research (2nd ed., pp. 61-90). Hillsdale, NJ: Lawrence Erlbaum.

Berkowitz, D. (1990). Refining the gatekeeping metaphor for local television news. Journal of Broadcasting \& Electronic Media, 34, 55-68. doi:10.1080/08838159009386725

Bortner, M. A. (1984). Media images and public attitudes toward crime and justice. In R. Surette (Ed.), Justice and the media (pp. 15-30). Springfield, IL: Thomas.

Brown, J. D. (2001). A comparison of fictional television crime and crime index statistics. Communication Research Reports, 18, 192-199. doi:10.1080/08824090109384797

Bushman, B. J., \& Anderson, C. A. (2001). Media violence and the American public: Scientific facts versus media misinformation. American Psychologist, 56, 477-489. doi:10.1037/0003-066X.56.6-7.477

Centerwall, B. S. (1989). Exposure to television as a risk factor for violence. American Journal of Epidemiology, 129, 643-652

Comstock, G. (1983). Media influences on aggresson. In A. Goldstein, \& L. Krasner (Eds.), Prevention and control of aggression (pp. 241272). Elmsford, NY: Pergamon Press.

Comstock, G., Chaffee, S., Katzman, N., McCombs, M., \& Roberts, D. (1978). Television and human behavior. NY: Columbia University Press.

Comstock, G., \& Scharrer, E. (1999). Television: What's on, who's watching and what it means. San Diego: Academic Press.

Diefenbach, D. L., \& West, M. D. (2001). Violent crime and Poisson regression: A measure and a method for cultivation analysis. Journal of Broadcasting \& Electronic Media, 45, 432-445. doi:10.1207/s15506878jobem4503_4

Diener, E., \& DuFour, D. (1978). Does television violence enhance program popularity? Journal of Personality and Social Psychology, 36, 333-341. doi:10.1037/0022-3514.36.3.333

Dominick, J. R. (1973). Crime and law enforcement on prime-time television. Public Opinion Quarterly, 37, 241-250.

doi:10.1086/268081

Donnerstein, E., \& \& Linz, D. (1995). The media. In J. Q. Wilson, \& J. Petersilia (Eds.), Crime (pp. 237-264). San Francisco: Institute for Contemporary Press.

Doppelt, J., \& Manikas, P. (1990). Mass media and criminal justice decision making. In R. Surette (Ed.), The media and criminal policy (pp. 129-142). Springfield, IL: Thomas.

Eron, L. D., \& Huesmann, L. R. (1980). Adolescent aggression and television. Annals of the New York Academy of Sciences, 347, 319-331. doi:10.1111/j.1749-6632.1980.tb21281.x

Fedler, F., \& Jordan, D. (1982). How emphasis on people affects coverage of crime. Journalism Quarterly, 17, 474-478. doi:10.1177/107769908205900321

Gerbner, G., Gross, L., Eleey, M., Jackson-Beeck, M., Jeffries-Fox, S., \& Signorielli, N. (1977). TV violence profile, No. 8: The highlights. Journal of Communication, 27, 171-180. doi:10.1111/j.1460-2466.1977.tb01845.x

Gerbner, G., Gross, L., Morgan, M., Signorielli, N., \& Shanahan, J. (2002). Growing up with television: Cultivation processes. In J. Bryant, \& D. Zillman (Eds.), Media effects: Advances in theory and research (2nd edition, pp. 43-67). Hillsdale, NJ: Lawrence Erlbaum.

Goldstein, M. (1973). Exposure to erotic and violent stimuli and sexual deviance. Journal of Social Issues, 29, 197-219.

doi:10.1111/j.1540-4560.1973.tb00096.x

Graber, D. (1980). Crime news and the public. NY: Praeger.

Greenberg, B. S., \& Collette, L. (1997). The changing faces on TV: A demographic analysis of network television's new seasons, 19661992. Journal of Broadcasting \& Electronic Media, 41, 1-13. doi:10.1080/08838159709364386

Greenberg, B. S., Simmons, K. W., Hogan, L., \& Atkin, C. K. (1980). The demography of fictional TV characters. In B. S. Greenberg (Ed.), Life on television: Content analyses of U.S. TV drama (pp. 99-128). Norwood, NJ: Ablex Publishing Corporation.

Grimes, T., Anderson, J., \& Bergen, L. (2008). Media violence and aggression: Science and ideology. Thousand Oaks, CA: Sage.

Head, S. W. (1954). Content analysis of television drama programs. Quarterly of Film, Radio and Television, 9, 175-194. doi:10.1525/fq.1954.9.2.04a00080

Heath L., \& Gilbert, F. (1996). Mass media and fear of crime. American Behavioral Scientist, 39, 379-386. doi:10.1177/0002764296039004003

Hennigan, K., Heath, L., Wharton, J. D., Del-Rosario, M. L., Cook, T. D., \& Calder, B. J. (1982). Impact of the introduction of television on crime in the United States: Empirical findings and theoretical implications. Journal of Personality and Social Psychology, 42, 461-477. doi:10.1037/0022-3514.42.3.461

Hetsroni, A. (2007). Forty years of violent content on prime-time network programming: A longitudinal meta-analytic review. Journal of Communication, 57, 759-784.

doi:10.1111/j.1460-2466.2007.00367.x

Hetsroni, A., \& Tukachinsky, R. H. (2006). TV world estimates and real world estimates: A new scheme for cultivation. Journal of Communication, 56, 133-156. doi:10.1111/j.1460-2466.2006.00007.x

Jermyn, D. (2006). Crimewatching: Investigating real crime TV. London: IB Tauris.

Lasswell, H. D. (1935). World politics and personal insecurity: A contribution to political psychiatry. NY: McGraw-Hill.

Lichter, L. S., \& Lichter, S. R. (1983). Prime time crime. Washington, DC: Media Institute.

Lichter, S. R., Lichter, L. S., \& Rothman, S. (1994). Prime time: How TV portrays American culture. Washington, DC: Regnery.

Lowery, S. A. \& DeFleur, M. L. (1995). Milestones in mass communication research: Media effects (3rd ed.). White Plains, NY: Longman.

Maguire, B. (1988). Image vs. reality: An analysis of prime-time television crime and police programs. Crime and Justice, 11, 165-188. doi:10.1080/0735648X.1988.9721362

Meyers, M. (1994). News of battering. Journal of Communication, 44, 47-63. doi:10.1111/j.1460-2466.1994.tb00676.x

Paik, H., \& Comstock, G. (1994). The effects of television violence on antisocial behavior: A meta-analysis. Communication Research, 21, 516-546. doi:10.1177/009365094021004004

Pease, S., \& Love, C. (1984). The copycat crime phenomenon. In R. Surette (Ed.), Justice and the media (pp. 199-211). Springfield, IL: Thomas.

Philips, D., \& \& Hensley, J. (1984). When violence is rewarded or punished: The impact of mass media stories on homicide. Journal of 


\section{A. HETSRONI}

Communication, 34, 101-116

doi:10.1111/j.1460-2466.1984.tb02178.x

Potter, W. J. (2003). The 11 myths of media violence. Thousand Oaks, CA: Sage.

Roman, J. (2005). From daytime to primetime: The history of American television programs. Westport, CT: Greenwood Press.

Saad, L. (2007. Perceptions of crime problem remain curiously negative. URL (last checked 22 October 2007).

http://www.gallup.com/poll/102262/Perceptions-Crime-Problem-Re main-Curiously-Negative.aspx

Scheingold, S. (1984). The politics of law and order. White Plains, NY: Longman.

Sheley, J., \& Ashkins, C. (1981). Crime, crime news and crime views. Public Opinion Quarterly, 45, 492-506. doi:10.1086/268683

Signorielli, N. (2005). Violence in the media: A reference handbook.
Santa-Barbara, CA: ABC-CLIO.

Smythe, D. W. (1954). Reality as presented by television. Public Opinion Quarterly, 18, 143-156. doi:10.1086/266500

Stark, S. (1987). Perry Mason meets Sonny Crocket: The history of lawyers and the police as television heroes. University of Miami Law Review, 42, 229-283.

Surette, R. (1998). Media, crime, and criminal justice: Images and realities (2nd ed.). New York: Wadsworth Publishing.

Terry, W. (1984). Crime and the news: Gatekeeping and beyond. In R. Surette (Ed.), Justice and the media (pp. 31-50). Springfield, IL: Thomas.

TV Guide (2006). Guide to TV. New York: Barnes \& Noble Publishing. Weimann, G. (2000). Communicating unreality: Modern media and the reconstruction of reality. Thousand Oaks, CA: Sage. 